\title{
Analysis the Influenced of Plain and Twill Structures on Woven Fabric Properties
}

\author{
Monour Khan ${ }^{*}$, Hasan Mahmud1, Tirtha Sarathi Das', Muhammad Abdullah', \\ Tushar Rahman Khan², Rokibul Hasan Shohan², Sajid Al Rafi², Solaiman'
}

${ }^{1}$ Department of Fabric Manufacturing Engineering, Textile Engineering College, Noakhali Affiliated by Bangladesh University of Textiles, Dhaka, Bangladesh

${ }^{2}$ Department of Wet Processing Engineering, Textile Engineering College, Noakhali Affiliated by Bangladesh University of Textiles, Dhaka, Bangladesh

Email: *monour.k.95@gmail.com, hasmahmudbd@gmail.com, tirthadas05@gmail.com, mdabdullah123tex@gmail.com, tushar1697@gmail.com, mdrokibulhasanshohan14@gmail.com, sajidalrafi@gmail.com, solaimanbari@gmail.com

How to cite this paper: Khan, M., Mahmud, H., Das, T.S., Abdullah, M., Khan, T.R., Shohan, R.H., Al Rafi, S. and Solaiman (2020) Analysis the Influenced of Plain and Twill Structures on Woven Fabric Properties. Journal of Textile Science and Technology, 6, 107-113. https://doi.org/10.4236/jtst.2020.63008

Received: December 19, 2019

Accepted: June 7, 2020

Published: June 10, 2020

Copyright ( 2020 by author(s) and Scientific Research Publishing Inc. This work is licensed under the Creative Commons Attribution International License (CC BY 4.0).

http://creativecommons.org/licenses/by/4.0/

\begin{abstract}
Fabric outer appearance is influenced by various fabric structures. In this research work, the physical properties of plain and twill were analyzed. Physical, mechanical and other aesthetic properties are also tested and the finding results are also compared between two samples. After testing the samples it is found that rubbing fastness remains unchanged for plain and twill fabric. Abrasion resistance, pilling, crease recovery and cover factor were evaluated for twill and plain structures using ISO 12945-2, ISO 12945-1 and ISO 2313 methods respectively. Abrasion resistance and pills property are not good for twill fabric in comparison with plain fabric but crease recovery is better of twill fabric.
\end{abstract}

\section{Keywords}

Abrasion, Pilling, Crease Recovery, Color Fastness, Cover Factor, EPI \& PPI

\section{Introduction}

Fabrics are produced in different techniques such as weaving, knitting, non-woven, etc. Fabric is called woven fabric, knit fabric, and non-woven fabric respectively on the basis of their manufacturing technique. Day by day the demand for woven is increased for its popularity and high essentiality of the fabric. Casual shirts and pants are produced from woven fabric. It also used for household purposes and technical purposes also [1]. About three billion meters of 
woven fabric is required for export every year but only about forty-five million meters of woven fabric is exported by us. This scenario showed the lacking of our woven fabric industry. For that it is essential to establish more and more woven factories to reduce the gap between supply and demand [2].

Woven fabric is produced by the interlacement of warp yarn that is longitudinal and weft yarn that is transverse and it is the most versatile fabric for its construction. It is the most sophisticated \& aristocratic fabric available with different designs. Plain, twill, satin etc. can be produced by variation of the interlacement of warp and weft yarn. These variations of the designs have changed mechanical properties of woven fabrics. For textile fabric it is described as a result of the material's resistance to the activity of external forces causing the change of shape [3]. As the properties of fabric vary according to their weave structure, we have taken two structures of woven fabric such as $1 / 1$ plain and $3 / 1$ $\mathrm{Z}$ twill to analyze the influence of plain and twill structures on woven fabric properties.

Plain weave is the basis of three fundamental types of textile weaves (along with satin weave and twill). In plain weave cloth, the warp and weft threads cross at right angles. Each weft thread crosses the warp threads by going over one, then under the next, and so on. The next weft thread goes under the warp threads that its neighbor went over, and vice versa [4]. Twill is a type of textile weave with a pattern of diagonal parallel ribs. It is one of three fundamental types of textile weaves along with plain weave and satin. It is made by passing the weft thread over one or more warp threads then under two or more warp threads and so on, with a "step", or offset, between rows to create the characteristic diagonal pattern [5].

The aim of this study is to identify the influence of plain and twill structures on woven fabric properties. From literature it is possible to detect that due to variation of fabric construction, the mechanical properties of the fabric also vary. Among various properties, for this experiment abrasion resistance, pilling resistance, crease recovery and cover factor of two different types of fabric designs were tested [6].

\section{Experimental}

Two samples of $100 \%$ cotton plain and twill grey fabrics are collected from the Gulshan Area City, Islampur, Dhaka. After collecting, the fabrics are analyzed very carefully. The GSM of both fabrics are 160, the warp yarn count and the weft yarn count of the plain sample is 40's and 32's and for the twill sample is 40 's and 30's respectively. The structures of the samples are $1 / 1$ plain and 3/1 Z twill. The cloth cover factors of the plain fabric are 22.65 and for twill fabric is 21.26 respectively. The ends per inch and the picks per inch for $1 / 1$ plain sample are 112 and 76 respectively and for $3 / 1 \mathrm{Z}$ twill sample are 100 and 56 respectively. These fabrics are collected for determining the influence of plain and twill structure on woven fabric properties. 


\section{Methods of Testing of Plain and Twill Fabric}

\subsection{Determination of Abrasion Resistance}

Cut the sample according to the template (Abrasion Dia. $3.75 \mathrm{~cm}$ \& Pilling Dia. $13.9 \mathrm{~cm}$ Cutter). For pilling same fabric is used (one test sample \& other the same fabric of test are required) and for abrasion one test sample \& one standard abrading fabric are required. Then for pilling, test sample is placed face down on pilling specimen holder and other fabric is placed face upward on piling table. Abrasion and Pilling Resistance are determined by ASTM D 4966 \& ISO 12945-2 for Abrasion and ASTM D 4970 \& ISO 12947-2 [7].

\subsection{Testing Procedure of Pilling Formation (ISO 12945-1)}

For this test four specimens each 5 inch $\times 5$ inch were cut from the fabric. A seam allowance of $12 \mathrm{~mm}$ was marked on the back of each square. In two of the samples the seam was marked parallel to the warp direction and in the other two parallel to the weft direction. The samples were then folded face to face and a seam was sewn on the marked line. This gave two specimens with the seam parallel to the warp and two with the seam parallel to the weft. Each specimen was turned inside out and $6 \mathrm{~mm}$ cut off each end of it thus removing any sewing distortion. The fabric tubes made were then mounted on rubber tubes so that the length of tube showing at each end was the same. Each of the loose ends was taped with poly (vinyl chloride) (PVC) tape so that $6 \mathrm{~mm}$ of the rubber tube was left exposed. All four specimens were then placed in one pilling box. The samples were then tumbled together in a cork-lined box. The usual number of revolutions used in the test was 18,000 which take $5 \mathrm{hrs}$ [8]. The specification of the machine was Brand: James Heal; Origin: UK; Model: 1516 ORBITOR; Volts: 110 - 230 V; Frequency: 50/60 Hz; Amp: 0.5 A; S/N: 1516/2/1014.

\subsection{Testing Procedure of Crease Recovery (ISO 2313)}

A specimen was cut from the fabrics with a template 2 inch long by 1 inch wide. It was carefully creased by folding in half placing it between two glass plates and adding a $2 \mathrm{~kg}$ weight. After $1 \mathrm{~min}$ the weight was removed and the specimen transferred to the fabrics clamp on the instrument and allowed to recover from crease. As it recovers, the dial of the instrument was rotated to keep the free edge of the specimen in line with the knife edge. At the end of the time period allowed for recovery, usually $1 \mathrm{~min}$ the recovery angle in degrees was read on the engraved scale. Warp and weft way recovery were reported separately to the nearest degree from the mean values of ten tests in each direction [9].

\subsection{Testing Procedure of Cover Factor}

Cover factor is a number that indicates the extent to which the area of a fabric is covered by one set of threads. For any woven fabric, there are two cover factors: a warp cover factor and a weft cover factor. Under the cotton system, the cover factor is the ratio of the number of threads per inch to the square root of the 
cotton yarn count. It is calculated by the following formula

$$
K_{c}=K_{1}+K_{2}-K_{1} * K_{2} / 28
$$

where, $K_{c}=$ Cloth cover factor

$K_{1}=$ Warp cover factor $=$ EPI $/$ Warp count

$K_{2}=$ Weft cover factor $=$ PPI/Weft count [10].

\subsection{Testing Procedure of Color Fastness to Rubbing (ISO 105-X12)}

Rubbing fastness is the resistance to fading of dyed textiles when rubbed against a rough surface. This test determines the fastness of dyestuff to either wet or dry rubbing. For rubbing fastness testing test specimen $15 \mathrm{~cm} \times 5 \mathrm{~cm}$ was placed on the base of the crock meter. Square of white test cloth $(5 \mathrm{~cm} \times 5 \mathrm{~cm})$ of cotton desized, bleached but without finish was attached to the finger of the crock meter. This finger was used in rubbing action on the sample specimen i.e. rubbing $10 \mathrm{~cm}$ long to and fro 10 times at 10 seconds. 20 rubs in $10 \mathrm{~s}$ and finger pressure on the specimen was $9 \mathrm{~N}$. For testing dry and wet rubbing separate specimen was used. Three specimens for dry and wet rubbing respectively in warp way direction and another three specimens for both rubbing respectively in weft direction were used for two different constructed samples. Change in color in the specimen and staining in the white cloth was determined by grey scale. The specification of the crock meter was Brand: James Heal; Origin: UK; Model: 670HD Crock Meter; Volts: N/A; Phase: N/A; Amps: N/A; Frequency: N/A; S/N: $670 / 15 / 143[11]$

\section{Results and Discussion}

\subsection{Determination of Abrasion Resistance}

The wear index indicates the abrasion resistance of both of the fabrics. The more the wear index (Table 1) indicates lower abrasion resistance properties. From the tables we can see that the average wear index (Table 2) of plain fabric is less than the twill fabric.

Due to less interlacement or more porous, twill weave is not so resistant to abrasion compares to plain.

\subsection{Determination of Pilling}

From Table 3, it's clear that the pill formation tendency of twill fabric is more

Table 1. Abrasion resistance of twill fabric.

\begin{tabular}{ccccccc}
\hline $\begin{array}{c}\text { No. } \\
\text { observation }\end{array}$ & $\begin{array}{c}\text { Sample weight } \\
\text { before } \\
(\mathrm{gm} .)\end{array}$ & $\begin{array}{c}\text { No. } \\
\text { Abrasion } \\
\text { cycle }\end{array}$ & $\begin{array}{c}\text { Sample weight } \\
\text { after abrasion } \\
(\mathrm{gm} .)\end{array}$ & $\begin{array}{c}\text { Weight } \\
\text { loss } \\
(\mathrm{gm} .)\end{array}$ & $\begin{array}{c}\text { Wear } \\
\text { index }\end{array}$ & $\begin{array}{c}\text { Avg. } \\
\text { Wear } \\
\text { index }\end{array}$ \\
\hline 1 & 0.274 & 10,000 & 0.256 & 0.018 & 180 & \\
2 & 0.274 & 10,000 & 0.255 & 0.019 & 190 & 176.67 \\
3 & 0.272 & 10,000 & 0.256 & 0.016 & 160 & \\
\hline
\end{tabular}


Table 2. Abrasion resistance of plain fabric.

\begin{tabular}{ccccccc}
\hline $\begin{array}{c}\text { No. } \\
\text { observation }\end{array}$ & $\begin{array}{c}\text { Sample } \\
\text { weight } \\
\text { before in } \\
\text { (gm.) }\end{array}$ & $\begin{array}{c}\text { No. } \\
\text { Abrasion } \\
\text { cycle }\end{array}$ & $\begin{array}{c}\text { Sample } \\
\text { weight after } \\
\text { abrasion } \\
\text { (gm.) }\end{array}$ & $\begin{array}{c}\text { Weight } \\
\text { loss } \\
(\mathrm{gm} .)\end{array}$ & $\begin{array}{c}\text { Wear } \\
\text { index }\end{array}$ & $\begin{array}{c}\text { Avg. } \\
\text { Wear } \\
\text { index }\end{array}$ \\
\hline 1 & 0.36 & 10,000 & 0.354 & 0.006 & 60 & \\
2 & 0.361 & 10,000 & 0.356 & 0.005 & 50 & 60 \\
3 & 0.359 & 10,000 & 0.352 & 0.007 & 70 & \\
\hline
\end{tabular}

Table 3. Pilling formation of plain and twill fabric.

\begin{tabular}{cccc}
\hline Specimen & Fabric type & Avg. Grade & Comments \\
\hline 1 & Twill & 3 & Moderate formations of pills. \\
2 & Plain & 4 & Weak formations of pills. \\
\hline
\end{tabular}

than the plain fabric. Due to less interlacement the migratory tendency of fibers from the constituent yarn is less in plain weave than twill. As a result, it is found that plain fabric is more resistant to pill formation than twill weaves.

\subsection{Determination of Fabric Crease Recovery}

Table 4 shows the comparative crease angle.

After completing the test we found crease recover angle (Table 4) of plain fabric is $105^{\circ}$ and twill fabric is $110^{\circ}$. So the crease formation of plain is much higher than twill fabric.

Due to the increase of the weft yarn count, the crease recovery angle increases for all types of weave structures.

\subsection{Determination of Cover Factor}

The comparative result of cloth cover is given in Table 5. The more the cloth cover the more compact the fabric will be. Here the cloth cover of plain fabric (22.65) is greater than the cloth cover of twill fabric (21.26). So the plain fabric is more compact.

\subsection{Determination of Color Fastness to Rubbing}

The comparative grey scale rating is given below.

From Table 6 it is seen that both of the fabric show good rubbing properties.

\section{Conclusion}

In this study, elaborate knowledge about the variation of mechanical properties (abrasion resistance, pilling resistance, crease recovery, color fastness to rubbing, cover factor) on the fabric structure of woven fabric was studied. After examination, we found that twill fabric has more wear index than plain fabric. Plain fabric has lower tendency to form pills in comparison with twill fabric. But crease 
Table 4. Crease recovery angle of twill and plain fabric.

\begin{tabular}{ccc}
\hline Sl. No. & Fabric & Avg. Crease recovery angle \\
\hline 1 & Twill & $110^{\circ}$ \\
2 & Plain & $105^{\circ}$ \\
\hline
\end{tabular}

Table 5. Cloth cover factor of plain and twill fabric.

\begin{tabular}{cccccccc}
\hline $\begin{array}{c}\text { Fabric } \\
\text { type }\end{array}$ & EPI & PPI & $\begin{array}{c}\text { Warp } \\
\text { Count } \\
\left(n_{1}\right)\end{array}$ & $\begin{array}{c}\text { Weft } \\
\text { Count } \\
\left(n_{2}\right)\end{array}$ & $\begin{array}{c}\text { Warp } \\
\text { Cover } \\
\left(k_{1}\right)\end{array}$ & $\begin{array}{c}\text { Weft } \\
\text { Cover } \\
\left(k_{2}\right)\end{array}$ & $\begin{array}{c}\text { Cloth } \\
\text { cover } \\
(k)\end{array}$ \\
\hline Plain & 112 & 76 & 40 & 32 & 17.70 & 13.44 & 22.65 \\
Twill & 100 & 56 & 40 & 30 & 17.39 & 10.22 & 21.26 \\
\hline
\end{tabular}

Table 6. Color fastness to rubbing of plain and twill fabric.

\begin{tabular}{ccc}
\hline Type of fabric & Avg. value of Grey scale & Comments \\
\hline Twill & 4 & Good \\
Plain & 4 & Good \\
\hline
\end{tabular}

recovery behaviors of twill are good than plain structure. Color fastness of rubbing is same for both structures. So we can say that a proper fabric structure can provide fabric with good quality of mechanical properties.

\section{Conflicts of Interest}

The authors declare no conflicts of interest regarding the publication of this paper.

\section{References}

[1] Amin, R. and Haque, M. (2011) Effect of Weave Structure on Fabric Properties. Annals of the University of Oradea, Fascicle of Textiles, Leatherwork, 12, 161-165.

[2] Jahan, I. (2017) Effect of Fabric Structure on the Mechanical Properties of Woven Fabrics. Advance Research in Textile Engineering, 2, 1018.

https://doi.org/10.26420/advrestexteng.2017.1018

[3] Booth, J.E. (1961) Principles of Textile Testing: An Introduction of Physical Methods of Testing Textile Fibers, Yarns and Fabrics. Chemical Publishing Co. Inc., New York.

[4] Emery, I. (1966) The Primary Structures of Fabrics. The George Washington University and Textile Museum Library, The Textile Museum, Washington DC, 76.

[5] Oelsner, G.H. (1915) A Handbook of Weaves. The Macmillan Company, New York, OCLC 2325693

[6] Realff, M.L., Seo, M., Boyce, M.C., Schwartaz, P. and Backer, S. (1991) Mechanical Properties of Fabrics Woven from Yarns Produced by Different Spinning Technologies: Yarn Failure as a Function of Gauge Length. Textile Research Journal, 61, 517-530. https://doi.org/10.1177/004051759106100904

[7] Solaiman, J.S. (2015) Comparative Analysis of Manual Fading and Laser Fading Process on Denim Fabric. Science Discovery, 3, 44-49. 
https://doi.org/10.11648/j.sd.20150306.11

[8] Periyasamy, A.P. (2012) Effect of Alkali Pretreatment and Dyeing on Fibrillation Properties of Lyocell Fiber. Proceedings of the RMUTP International Conference: Textiles \& Fashion, Bangkok, 3-4 July 2012, 1-11.

[9] Leeder, J.D., Rippon, J.A., Roche, P.H. and Taylor, D.S. (1981) Standard Crease-Recovery Tests for Textiles: Non-Standard Results Caused by Pre-Test Procedures. Journal of the Textile Institute, 72, 42-44. https://doi.org/10.1080/00405008108631583

[10] Angappan, P. (2009) Textile Testing: Fibers Testing, Yarns Testing, Fabrics Testing and Quality Control.

[11] Kamel, M.M., El-Shishtawy, R.M., Yussef, B.M. and Mashaly, H. (2005) Ultrasonic Assisted Dyeing: III. Dyeing of Wool with Lac as a Natural Dye. Dyes and Pigments, 65, 103-110. https://doi.org/10.1016/j.dyepig.2004.06.003 